\title{
High-flow nasal cannula may be no safer than non-invasive positive pressure ventilation for COVID-19 patients
}

\author{
Kenneth E. Remy ${ }^{1}$, John C. Lin ${ }^{2}$ and Philip A. Verhoef ${ }^{3 *}$
}

To the Editor:

We have read with great interest the Surviving sepsis campaign: guidelines on the management of critically ill adults with coronavirus disease 2019 (COVID-19) [1]. We are very concerned on the recommendation to use high-flow nasal cannula (HFNC) over non-invasive positive pressure ventilation (NIPPV).

We agree that HFNC has previously demonstrated reduced 90-day mortality compared to NIPPV in patients with acute hypoxemic respiratory failure [2] and that NIPPV has been demonstrated to have increased risk of aerosolized transmission to health care workers [3]. However, the differences in this risk with NIPPV compared to HFNC are largely unknown. Presently, it is known that COVID-19 (SARS-CoV-2) compared to SARS-CoV-1 remains viable in aerosols for at least $3 \mathrm{~h}$ with a marginal reduction in infectious titer from 103.5 to 102.7 TCID50 per liter of air [4]. Likewise, it showed a higher stability on plastic and stainless steel than on copper and cardboard, with virus viability seen up to 72 $h$ on these surfaces [4]. This provides a concerning phenomenon for both HFNC and NIPPV as both interfaces are plastic with potential for aerosolization. An important difference is that the NIPPV interface provides a potential closed system (which may be advantageous) whereas HFNC allows patients to frequently touch their faces with continuous exposure to droplets, potentially increasing transmission to inanimate surfaces and hospital workers.

In 2019, Leung and colleagues found that HFNC use was not associated with increased air or contact surface

\footnotetext{
* Correspondence: Philip.verhoef@gmail.com

${ }^{3}$ University of Hawaii-Manoa, Kaiser Permanente Hawaii, Honolulu, HI, USA Full list of author information is available at the end of the article
}

bacterial contamination compared to simple oxygen mask in critically ill patients [5]. Unfortunately, viruses were not included in this study. Likewise, the term "aerosol" is a misnomer as it is well described that larger particle droplets can remain longer in circulation if ambient airflows (as in HFNC) sustain the infectious suspension for a longer duration. This, coupled with data from influenza infections showing aerosolized viruses are infectious at a lower dose than by nasal instillation, makes use of HFNC potentially worrisome [6]. The only known study evaluating SARS development in hospital workers was a retrospective study conducted prior to the widespread use of HFNC showing that development of SARS occurred in tracheal intubation (35\%), HFNC 8\%, and 38\% (NIPPV) [3]; this suggests that both noninvasive (including HFNC) and invasive ventilation approaches carry significant risk.

Undeniably, HFNC provides more comfort to patients and likely improved compliance. However, since the data regarding transmission are unclear, we suggest, in addition to a negative pressure room, reverse isolation protection efforts with patients on HFNC wearing a mask over the nasal interface or a contained respiratory hood.

\section{Acknowledgements} Not applicable

\section{Authors' contributions}

$K R, P V$, and $J L$ all contributed equally to the conception and drafting of this manuscript. All authors read and approved the final manuscript.

\section{Funding \\ Not applicable.}

\section{Availability of data and materials Not applicable.}


Ethics approval and consent to participate

Not applicable

\section{Consent for publication}

Not applicable

\section{Competing interests}

The authors declare that they have no competing interests.

\section{Author details}

${ }^{1}$ Pediatrics and Internal Medicine, Adult and Pediatric Critical Care Medicine, Washington University in St. Louis, St. Louis, MO, USA. ${ }^{2}$ Division of Pediatrics and Critical Care Medicine, Washington University School of Medicine, Saint Louis, MO, USA. ${ }^{3}$ University of Hawaii-Manoa, Kaiser Permanente Hawaii, Honolulu, HI, USA.

Received: 6 April 2020 Accepted: 14 April 2020

Published online: 23 April 2020

\section{References}

1. Alhazzani W, Moller MH, Arabi YM, et al. Surviving sepsis campaign: guidelines on the management of critically ill adults with coronavirus disease 2019 (COVID-19). Crit Care Med Released on March 20. PMID: 32224769. https://doi.org/10.1097/CCM.0000000000004363.

2. Frat JP, Thille AW, Mercat A, et al. High-flow oxygen through nasal cannula in acute hypoxemic respiratory failure. New Engl J Med. 2015;372(23):2185-96.

3. Raboud J, Shigayeva A, McGeer A, et al. Risk factors for SARS transmission from patients requiring intubation: a multicentre investigation in Toronto, Canada. PLoS One. 2010;5(5):e10717.

4. van Doremalen N, Bushmaker T, Morris DH, et al. Aerosol and surface stability of SARS-CoV-2 as compared with SARS-CoV-1. N Engl J Med. 2020; 382(16):1564-7. https://doi.org/10.1056/NEJMc2004973.

5. Leung $\mathrm{CCH}$, Joynt $\mathrm{GM}$, Gomersall $\mathrm{CD}$, et al. Comparison of high-flow nasal cannula versus oxygen face mask for environmental bacterial contamination in critically ill pneumonia patients: a randomized controlled crossover trial. J Hosp Infect. 2019;101(1):84-7.

6. Alford RH, Kasel JA, Gerone PJ, et al. Human influenza resulting from aerosol inhalation. Proc Soc Exp Biol Med. 1966;122(3):800-4.

\section{Publisher's Note}

Springer Nature remains neutral with regard to jurisdictional claims in published maps and institutional affiliations.

Ready to submit your research? Choose BMC and benefit from:
- fast, convenient online submission
- thorough peer review by experienced researchers in your field
- rapid publication on acceptance
- support for research data, including large and complex data types
- gold Open Access which fosters wider collaboration and increased citations
- maximum visibility for your research: over 100M website views per year
At BMC, research is always in progress.
Learn more biomedcentral.com/submissions

